Dept. of Internal Medicine,

Fac. Vet. Med., Assiut Univ.

\title{
RESIDUES OF HEAVY METALS AND THEIR EFFECT ON THE LIVER AND KIDNEY OF SHEEP FED SEWAGE POLLUTED PASTURES IN ASSIUT GOVERNORATE
}

(With 3 Tables and 2 Figures)

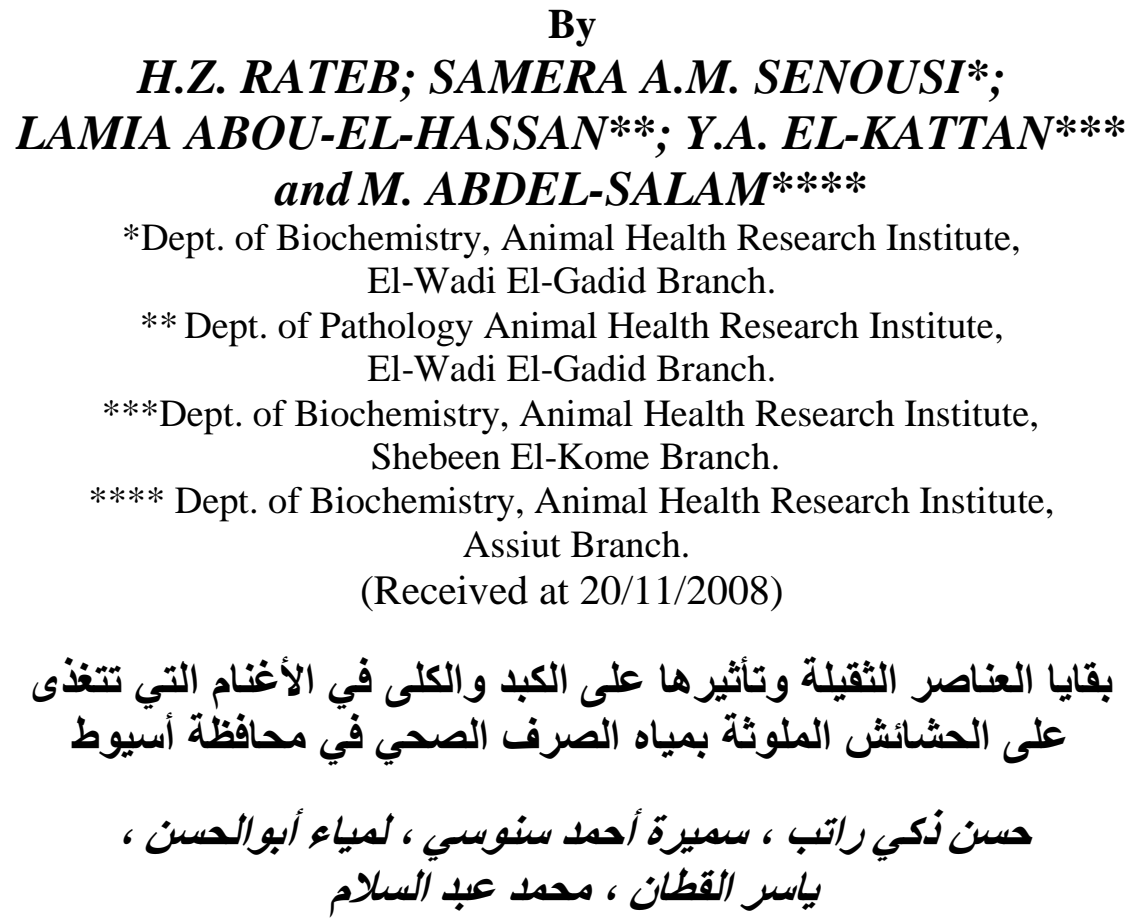

الهدف من هذه الدراسة تقييم تركيز كل من الرصساص و الكادميوم في أنسجة كبد وكلى الأغنام

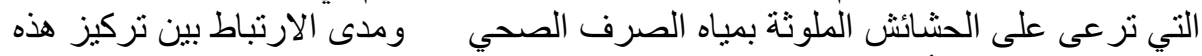

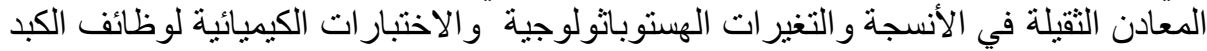

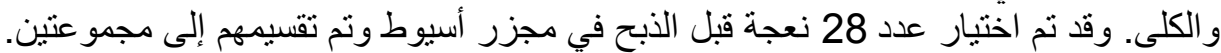
المجمو عة الأولى كانت تتكون من 12 نعجة ترعى في منطقة

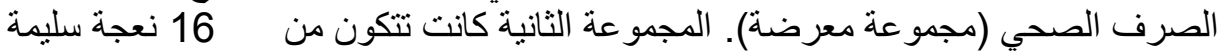

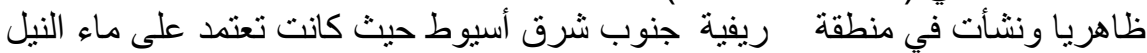

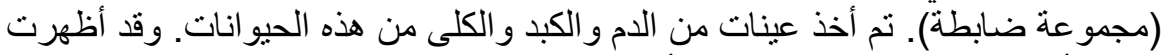

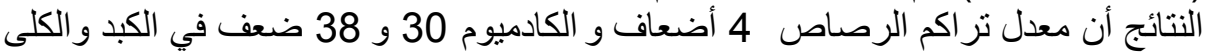

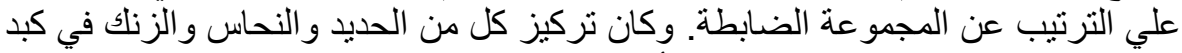
وكلى النعاج في الحدود المسموح بها. و أدى زيادة العناصر التقيلة إلى تغير ات في في التركيب التيب 


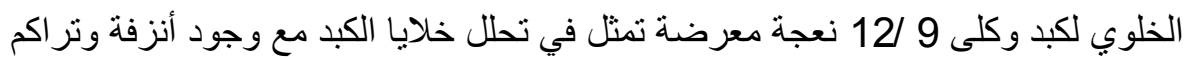

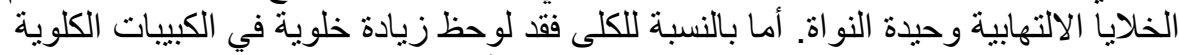

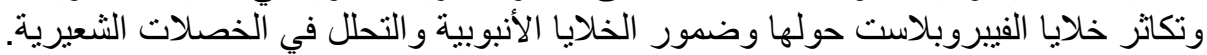

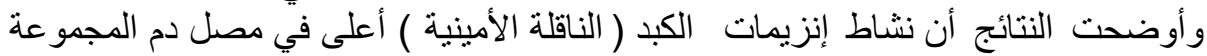

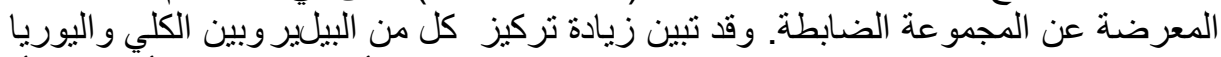

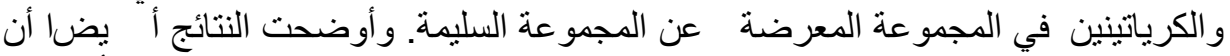

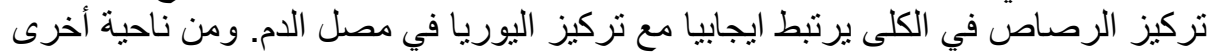

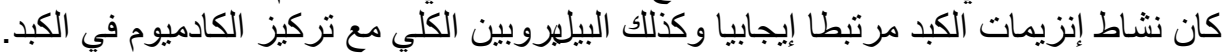

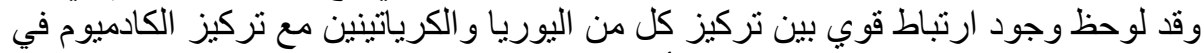

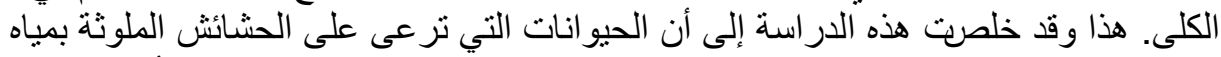

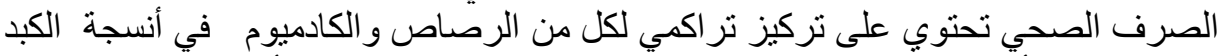

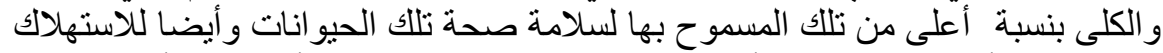

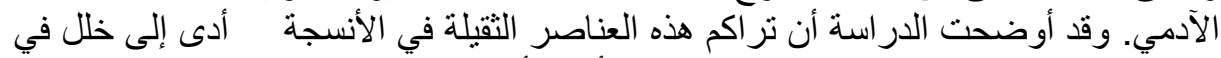

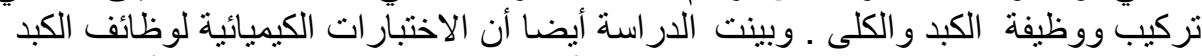

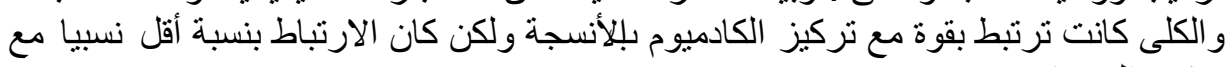

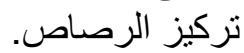

\section{SUMMARY}

The present work aimed to evaluate lead and cadmium concentrations in the liver and kidney of sheep reared on sewage polluted pastures. The degree of liver and kidney damages were evaluated biochemically and histopathologically. Twenty eight ewes (4-5 years) were selected before slaughtering from Assiut abattoir and classified into 2 groups. The first group (12 ewes, exposed) originated in a sewage polluted area (Arab ElMadabegh area). The second group (16 ewes, control) was selected from animals reared in a rural area in the southern east of Assiut, where irrigation was carried out by the River Nile water. Blood and tissues (liver and kidney) were sampled. Liver and kidney of exposed ewes accumulated higher concentrations of $\mathrm{Pb}$ (more than 4 fold, at $\mathrm{P}<0.001$ ) and $\mathrm{Cd}$ (30 fold and 39 fold, $\mathrm{P}<0.001$, respectively) than controls. Concentrations of $\mathrm{Cu}, \mathrm{Zn}$ and $\mathrm{Fe}$ in liver and kidney of exposed and control ewes were within the permissible limits. Heavy metal leaded to structural changes in the liver and kidneys of 9/12 exposed ewes. These changes were represented by necrosis in hepatocytes accompanied with hemorrhages and accumulation of mononuclear inflammatory cells. The glomeruli appeared hypercellular surrounded with fibroblastic proliferation, accompanied by atrophy of tubular epithelia and necrobiotic changes in the capillary tuft. The serum of exposed group showed higher AST and ALT activities $(\mathrm{P}<0.05)$, higher concentrations 
of total bilirubin $(\mathrm{P}<0.05)$, urea $(\mathrm{P}<0.05)$ and creatinine $(\mathrm{P}<0.01)$ than the control values. The accumulation of $\mathrm{Pb}$ in the liver was positively $(\mathrm{P}<0.05)$ correlated with serum ALT activity. The $\mathrm{Pb}$ concentration in the kidney was positively $(\mathrm{P}<0.05)$ correlated with serum urea concentrations. On the other hand concentrations of $\mathrm{Cd}$ in the liver were positively correlated with AST and ALT activities $(\mathrm{P}<0.05)$ and the concentrations of total bilirubin $(\mathrm{P}<0.01)$ in serum. A strong correlation $(\mathrm{P}<0.001)$ was noticed between the concentrations on serum urea and creatinine and the concentrations of $\mathrm{Cd}$ in the kidney. In conclusion, animals reared on sewage polluted pasture accumulate higher $\mathrm{Pb}$ and $\mathrm{Cd}$ in the liver and kidney than the recommended levels for health of these animals and for human consumption. This accumulation of heavy metal resulted in structural and functional hepatic and renal disorders. Also, the liver and kidney function tests were strongly correlated with $\mathrm{Cd}$ and relatively to less extent with $\mathrm{Pb}$ concentrations in these tissues.

Key words: Heavy metals, liver, kidney, sheep, sewage polluted pastures

\section{INTRODUCTION}

Land application of sewage sludge is a technique widely used around the world (WHO, 2005). The application of sewage sludge to grassland can lead to the accumulation of potentially toxic elements at the soil surface that may be ingested, together with herbage, by grazing ruminants (Thornton, 2002). The growing problem of contaminated land has focussed on the protection of human and animal health and of ecosystem (Thornton, 2002). Therefore, knowledge of the levels of lead and cadmium in livestock is important for assessing the potential effects of pollutants on domestic animals themselves and in quantifying contaminant intake in humans (Wilkinson et al., 2003).

Understanding the pathogenesis of contaminants strengthens our ability to quantify or to predict the likelihood of effects (ATSDR, 2005). El-Sharkawy et al. (2008) reported that the exposure to $\mathrm{Pb}$ and $\mathrm{Cd}$ have hazardous influence on the essential minerals profile in the blood of sheep. The authors found that $\mathrm{Pb}$ had a more hazardous influence than $\mathrm{Cd}$ on $\mathrm{Fe}$ metabolism, but $\mathrm{Cd}$ has a more deleterious effect than $\mathrm{Pb}$ on $\mathrm{Cu}$ and $\mathrm{Zn}$ metabolism. So that the authors emphasized a relation between the environmental exposure to heavy metals and the nutritional problems occur in the exposed animals. An association between cadmium and lead poisoning and renal disease in mammals has been recognized (WHO, 2005). The major renal effect of cadmium and lead 
poisoning is disruption of proximal tubular architecture, with laboratory evidence of disturbances in proximal tubular function (Nolan and Shaikh, 1992 and Stoev et al., 2003). Damek-Poprawa and SawickaKapusta (2004) noticed that even a relatively low body burden of lead and cadmium can lead to histopathological changes in the liver and kidney of animals chronically exposed to heavy metals.

The aim of the present work was the evaluation of lead and cadmium concentrations in the liver and kidney of sheep reared on sewage polluted plants at Assiut city, and to estimate the correlation values between the concentration of these heavy metal and the biochemical function tests of the liver and kidney of these sheep.

\section{MATERIALS and METHODS}

\section{Animals:}

Twenty eight non-pregnant non-lactating ewes (4-5 years) were selected before slaughtering at Assiut abattoir and classified into 2 groups. The first group (12 exposed ewes) had a history of rearing throughout all their life on a sewage polluted area in Arab El-Madabegh area. The second group (16 controls) was clinically healthy. The control group was selected from animals reared along their life in a rural area in the southern east part of Assiut city, where irrigation was carried out by the River Nile water. All ewes were subjected to careful clinical examinations to ensure their healthy status. Fecal samples were taken from the rectum of each ewe, and examined by the standard flotation sedimentation technique (Coles, 1980). Cases harboring gastrointestinal parasites were not selected.

\section{Sampling:}

Blood samples without anticoagulant, each of $10 \mathrm{ml}$, were obtained before slaughtering from the jugular vein of all ewes. After slaughtering, representative samples from the liver and kidney were taken for determination of heavy metals and for histopathological studies.

Tissues (for heavy metal determinations) and blood samples were iced in plastic bags and immediately transported to the laboratory. Blood was centrifuged for serum separation. Both tissue and serum samples were stored at $-20{ }^{\circ} \mathrm{C}$ until analysis.

For histopathological studies, slices of tissue samples were fixed immediately in the abattoir in $10 \%$ neutral buffered formalin. In the 
laboratory these slices were processed for paraffin embedment, sectioned at $6 \mu \mathrm{m}$ and stained with hematoxylin-eosin (H\&E).

\section{Analysis:}

For elemental determination, 2-ml serum and 0.5-g tissue samples were wet digested (AOAC, 1995). Concentrations of $\mathrm{Fe}, \mathrm{Cu}, \mathrm{Zn}$ $\mathrm{Pb}$ and $\mathrm{Cd}$ in tissue and serum samples was carried out using atomic absorption spectrophotometer (Perkin-Elmer 4300 AA). Blood serum was used for the biochemical analysis of the activity of alanine aminotransferase (ALT), aspartate aminotransferase (AST) and the concentrations of total bilirubin, blood urea nitrogen and creatinine (Henry et al., 1974) using test kits (Boehringer Mannheim, Germany).

\section{Statistical analysis:}

Data were expressed as means \pm standard error (SE). Differences between groups were determined using an analysis of variance followed by the Student t-test. Pearson's correlation (r) was performed on paired data obtained by individual cases according to Borenstein et al. (1997). Significance level was set at $\mathrm{P} \leq 0.05$.

\section{RESULTS}

\section{Metal concentrations in the liver and kidney:}

The mean values of heavy metal concentrations in the liver and kidney are presented in Table 1 . The mean concentrations of $\mathrm{Pb}$ in the liver and kidney of exposed ewes were higher (more than 4 fold, $\mathrm{P}<0.001)$ than the corresponding values in control animals. Liver and kidney of exposed ewes accumulated higher $\mathrm{Cd}$ concentrations (30 fold $\mathrm{P}<0.001$ and 38 fold $\mathrm{P}<0.001$ respectively) than the corresponding values in control ewes.

The mean concentrations of $\mathrm{Cu}$ and $\mathrm{Zn}$ in the liver were higher $(\mathrm{P}<0.05, \mathrm{P}<0.01$ respectively) in the exposed ewes if compared with control ewes. The mean value of $\mathrm{Zn}$ concentration of the exposed animals was higher $(\mathrm{P}<0.05)$ than the value reported in control animals. The mean concentrations of $\mathrm{Cu}$ in the kidney and $\mathrm{Fe}$ in the liver and kidney of exposed ewes did not differ than the values recorded in the non-exposed animals.

\section{Biochemical functions of the liver and kidney:}

Table 2 and Fig. $2 \& 3$ show the indices of the liver and kidney function in control and exposed ewes. The exposed group showed significantly higher activity of the hepatic enzymes AST $(\mathrm{P}<0.05)$ and ALT $(\mathrm{P}<0.05)$ when compared with the values of control animals. The 
mean concentration of the total bilirubin was significantly higher $(\mathrm{P}<0.05)$ and albumin was significantly lower $(\mathrm{P}<0.01)$ in the exposed ewes than the values detected in control animals. The exposed ewes showed higher mean values of the indices of kidney function including blood urea nitrogen $(\mathrm{P}<0.05)$ and creatinine $(\mathrm{P}<0.01)$ than the corresponding values of the control ewes.

\section{Histopathological changes of the liver and kidney:}

\section{The liver:}

The histology of the control liver was normal (Fig. 2A). The accumulation of heavy metal residues lead to liver cell destruction. The cytoplasm of some hepatocytes was enlarged, with vacuoles. In addition, there was intercellular hemorrhages, centrolobular granular degeneration and necrosis in hepatocytes (Fig. 2B). The trabecular structure of the lobules was blurred in places accompanied with accumulation of mononuclear cells in the vicinity of widened sinusoids (Fig. 2C). A mononuclear inflammatory cell infiltration extended from portal areas and disrupts the limiting plate of hepatocytes which were undergoing necrosis, resulting in chronic active hepatitis (Fig. 2D).

\section{The kidneys:}

The histology of the control kidneys was normal (Fig. 3A). The injury of heavy metals affected the main resorptive part (proximal convoluted tubules and straight tubules) and the filtering part (glomeruli) of the nephron. A lack of regular contour of glomeruli was noted and widening of filtering space accompanied with atrophy of tubular epithelia was evident (Fig. 3B). There was also a hypercellularity of the glomeruli and evidences of necrobiotic changes in the capillary tuft accompanied by infiltration of inflammatory cells, and the tubules filled with hyaline casts (Fig. 3C). Furthermore, a fibroblastic proliferation around the glomeruli was observed (Fig. 3D).

Table 1: The mean values of heavy metal concentrations ( $\mathrm{ppm})$ in the liver and kidney of sheep.

\begin{tabular}{|c|c|c|c|c|c|c|}
\hline Organ & Group & $\mathrm{Pb}$ & $\mathrm{Cd}$ & $\mathrm{Cu}$ & $\mathrm{Zn}$ & $\mathrm{Fe}$ \\
\hline Liver & Control & $0.294 \pm 0.06$ & $0.041 \pm 0.008$ & $59.1 \pm 5.2$ & $68.2 \pm 6.1$ & $79.1 \pm 7.9$ \\
& Exposed & $1.61 \pm 0.3^{* * *}$ & $1.26 \pm 0.4 * * *$ & $68.1 \pm 6.6^{*}$ & $83.8 \pm 8.2^{* *}$ & $86.6 \pm 8.6^{\mathrm{NS}}$ \\
\hline Kidney & Control & $0.389 \pm 0.09$ & $0.083 \pm 0.007$ & $12.9 \pm 1.6$ & $9.5 \pm 1.4$ & $29.8 \pm 3.8$ \\
& Exposed & $2.04 \pm 0.5^{* * *}$ & $3.25 \pm 0.6^{* * *}$ & $14.4 \pm 1.9^{\mathrm{NS}}$ & $14.2 \pm 2.9^{*}$ & $32.4 \pm 5.4^{\mathrm{NS}}$ \\
\hline
\end{tabular}

$*, * *, * * *$ : the levels of significance at $\mathrm{P}<0.05,0.01$ and 0.001 respectively.

NS: non-significant $(\mathrm{P}<0.05)$ 
Table 2: The indices of the liver and kidney function in healthy and exposed ewes.

\begin{tabular}{|l|c|c|}
\hline Liver and kidney function test & Control & Exposed \\
\hline Aspartate aminotransferase (IU/l) & $49.2 \pm 2.42$ & $64.6 \pm 2.91^{*}$ \\
\hline Alanine aminotransferase (IU/l) & $41.8 \pm 2.91$ & $73.8 \pm 3.5^{*}$ \\
\hline Total bilirubin $(\mathrm{mg} / \mathrm{dl})$ & $0.26 \pm 0.063$ & $0.39 \pm 0.081^{*}$ \\
\hline Urea $(\mathrm{mg} / \mathrm{dl})$ & $46.7 \pm 2.61$ & $57.8 \pm 2.54^{*}$ \\
\hline Creatinine $(\mathrm{mg} / \mathrm{dl})$ & $1.23 \pm 0.043$ & $1.96 \pm 0.051^{* *}$ \\
\hline
\end{tabular}

**** the levels of significance difference between exposed and control groups at $\mathrm{P}<0.05$ and 0.01 respectively. NS: non-significant $(\mathrm{P}<0.05)$
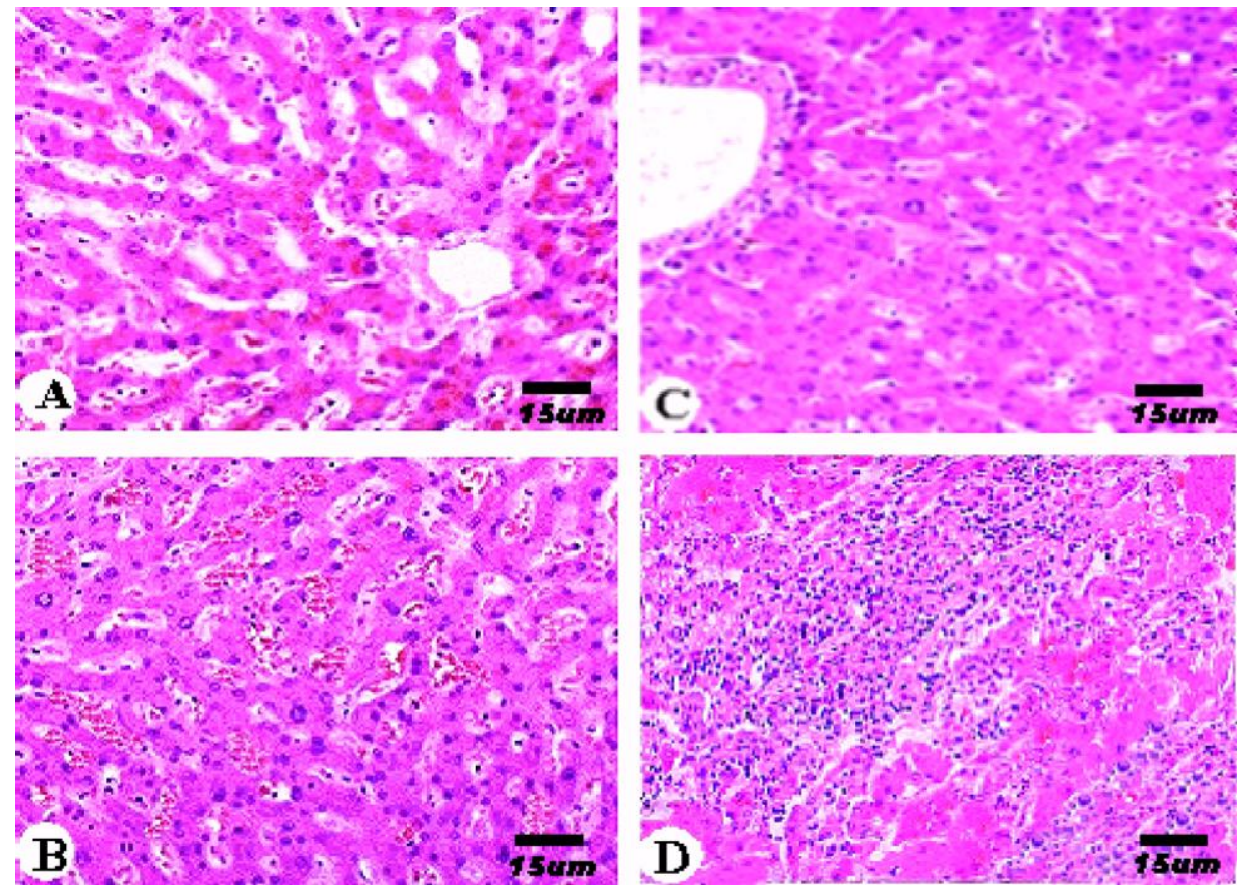

Fig. 1: Liver of sheep (H\&E). A: Control liver with normal structure (x300). $\mathrm{B}$ : Interstitial hemorrhages and centrolobular granular degeneration and necrosis in hepatocytes (x300). C: The structure of the lobules is blurred in addition to necrosis of the hepatocytes accompanied with accumulation of mononuclear cells in the vicinity of widened sinusoids (x300). D: A mononuclear inflammatory cell infiltrate extends from portal areas and disrupts the limiting plate of hepatocytes, which are undergoing coagulative necrosis, resulting in chronic active hepatitis (x300). 

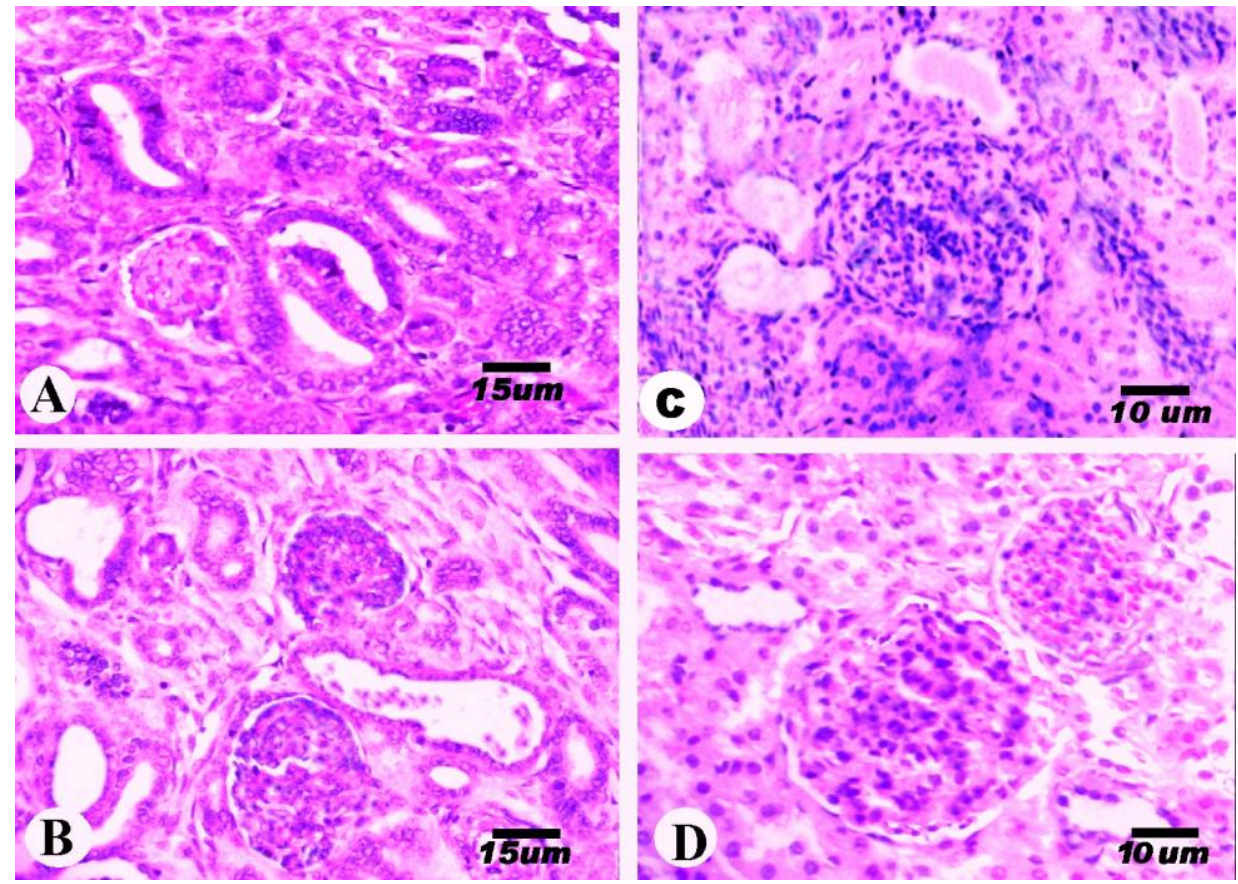

Fig. 2: Kidney of sheep (H\&E). A: Control kidney with normal structure (x250). B: Lack of regular contour of glomeruli and widening of filtering space, Granular degeneration in the epithelium of the proximal tubules accompanied with atrophy of tubular epithelia, some tubules contain single desquamated cells (x250). C: Hypercellularity of the glomeruli and evidences of necrobiotic changes in the capillary tuft and tubules filled with hyaline casts (x400). D: Peri-glomerular fibrosis, glomeruli are enlarged, tightly filling the Bowmann's capsule (x400).

Table 3: Correlation of $\mathrm{Pb}$ and $\mathrm{Cd}$ concentrations in the liver and indices of liver and kidney functions.

\begin{tabular}{|l|c|c|}
\hline Parameter & Lead $(\mathrm{ppm})$ & Cadmium $(\mathrm{ppm})$ \\
\hline Aspartate aminotransferase (IU/l) & $0.25^{\mathrm{NS}}$ & $0.33^{*}$ \\
\hline Alanine aminotransferase (IU/l) & $0.31^{*}$ & $0.36^{*}$ \\
\hline Total bilirubin $(\mathrm{mg} / \mathrm{dl})$ & $0.24^{\mathrm{NS}}$ & $0.44^{* *}$ \\
\hline Urea $(\mathrm{mg} / \mathrm{dl})$ & $0.32^{*}$ & $0.66^{* * *}$ \\
\hline Creatinine $(\mathrm{mg} / \mathrm{dl})$ & $0.28^{\mathrm{NS}}$ & $0.57^{* * *}$ \\
\hline
\end{tabular}

$*$,*** : the levels of significance of the correlation at $\mathrm{P}<0.05$ and 0.001 respectively.

NS: non-significant $(\mathrm{P}<0.05)$ 


\section{DISCUSSION}

Sewage sludge contains a mixture of man-made chemicals as well as inorganic compounds and heavy metals such as cadmium and lead (Smith 1995). Gomah (2001) found high concentrations of $\mathrm{Pb}$ and $\mathrm{Cd}$ in the pastures used for feeding ruminants at Arab El-Madabegh region. In the same area, El-Sharkawy (2008) found also higher concentrations of $\mathrm{Pb}$ ( $>2$ fold) and $\mathrm{Cd}(>11$ fold) polluted foods than the values in non-polluted foods. In the current study, exposed ewes showed higher concentrations of $\mathrm{Pb}$ and $\mathrm{Cd}$ in the liver and kidney than control animals. Concentrations of the bio-elements $\mathrm{Cu}, \mathrm{Zn}$ and $\mathrm{Fe}$ in exposed and control ewes were within the physiological limits as mentioned by Underwood and suttle (1999) and McDowell (2003)

The concentrations of $\mathrm{Pb}$ and $\mathrm{Cd}$ in the liver and kidney in the current study were higher than the normal values and lower than the poisoning levels recommended for sheep. Underwood and suttle (1999) reported that the normal $\mathrm{Pb}$ level in sheep is $0.1-.05 \mathrm{ppm}$ in the liver and kidney and the normal $\mathrm{Cd}$ level is $0.02-0.05 \mathrm{ppm}$ in the liver and $0.03-0.1 \mathrm{ppm}$ in the kidney. However, $\mathrm{Pb}$ concentrations greater than 8 $\mathrm{mg} / \mathrm{kg}$ in liver, $20 \mathrm{mg} / \mathrm{kg}$ in kidney cortex are indicative of $\mathrm{Pb}$ poisoning, but $\mathrm{Cd}$ concentrations greater than $50 \mathrm{mg} / \mathrm{kg}$ in liver, $100 \mathrm{mg} / \mathrm{kg}$ in kidney cortex are indicative of Cd poisoning (McDowell, 2003). The higher concentrations of $\mathrm{Cd}$ in the kidney than the liver concur with the reports of the Commission of the European Communities (CEC, 2001) who documented that the kidney cadmium concentration in sheep is twice that of the liver ( $1 \mathrm{ppm}$ compared to $0.5 \mathrm{ppm}$ ). The kidney is the critical organ after long-term occupational or environmental exposure to cadmium (ATSDR, 2005). The slower accumulation of $\mathrm{Cd}$ in the liver than the kidney may be related to the fact that cadmium may first be taken up into the liver, but then bound to metallothionein and subsequently released to the blood stream only to be taken up selectively by the kidney where it accumulates (WHO, 2005).

In the current work, the $\mathrm{Pb}$ and $\mathrm{Cd}$ concentrations in the liver and kidney of sheep were higher than the permissible values for human consumption cited by the CEC (2001). WHO (2005) demonstrated that the established maximum regulatory levels for animal products $(\mathrm{mg} / \mathrm{kg})$ were 0.5 for $\mathrm{Cd}$ and 0.5 for $\mathrm{Pb}$ in the liver and 1.0 for $\mathrm{Cd}$ and 0.5 for $\mathrm{Pb}$ in the Kidney. Accordingly, the liver and kidney of sheep reared on untreated sewage in the current work are not satisfactory for human consumption. Prankel, et al. (2004) suggested that the higher 
concentrations of heavy metals in sheep offal might be achieved by preventing the livers and kidneys of older animals from entering the human food chain. Similar results were also obtained by Abou-Arab (2001) who found that the $\mathrm{Pb}$ and $\mathrm{Cd}$ in the liver and kidney of sheep in polluted areas were higher than in the same organs of rural areas and concluded that the consumption of liver and kidney from animals in polluted areas should be avoided.

The effect of heavy metals on the liver and kidney pathology in the current study included the development of hepatic necrosis, renal proximal tubular dysfunction and glomerular damage. Similar results were also obtained by Stoev et al. (2003) and Damek-Poprawa and Sawicka-Kapusta (2004). The direct action of these heavy metals probably induces irritative effect and inflammation on the exposed tissues (Stoev et al., 2003). In addition, oxidative stress appears to play a major role in chronic $\mathrm{Pb}$ and $\mathrm{Cd}$-induced hepatic and renal inflammation and damages resulting in toxicity and damage of the exposed tissues (Shaikh, et al., 1999; Hsu and Guo, 2002; Kowalczyk et al., 2003 and Babu et al., 2006).

The activities of serum ALT and AST and the concentrations of total bilirubin are considered as biomarkers for liver function (Tenant, 1997). Blasco and Puppo (1999) and Kowalczyk et al. (2003) found that the damaging effect of cadmium on the liver is manifested by an increase of AST and of the most specific marker of liver cell damage. The present finding of the significantly higher activity of serum AST and ALT, higher concentrations of total bilirubin clearly suggested hepatic dysfunction in sheep reared on pastures irrigated with sewage wastewater.

In the current study, the correlation coefficient between $\mathrm{Cd}$ concentrations and hepatic functions revealed that $\mathrm{Cd}$ concentrations in the liver were significantly correlated with the activities of serum ALT and AST and the concentrations of total bilirubin. This indicates the presence of link between the degree of the liver dysfunction and the levels of cadmium in the liver. On the other hand, the correlation between $\mathrm{Pb}$ concentrations in the liver and the hepatic function indices was not as strong as Cd, except for ALT activity, suggesting a less association between $\mathrm{Pb}$ concentrations and the hepatic functions. Previous research had indicated that lambs could tolerate $1000 \mathrm{ppm}$ of $\mathrm{Pb}$ (Fick et al., 1976). Also, Neathery et al. (1990) found that concentration of $15.2 \mathrm{ppm} \mathrm{Pb}$ in the liver did not adversely affect the hepatic function as measured by liver enzymes activity. 
Serum concentrations of urea and creatinine are considered hallmarks of renal affections and kidney damage (Burtis and Ashwood, 1994). The kidney is the target organ for damage by heavy metals (WHO. 2005). In the current work, both serum urea and creatinine were significantly elevated in the exposed ewes than in controls indicating decreased clearance of urea and creatinine. Concentrations of $\mathrm{Pb}$ showed significant positive correlation with the concentration of serum urea and did not correlate with serum creatinine concentrations. On the other hand, serum Cd concentrations showed significant correlation with both serum urea and creatinine concentrations. This indicates that the damage of the kidney is increased by increasing $\mathrm{Pb}$ and $\mathrm{Cd}$ concentration. These findings also suggest that the concentration of $\mathrm{Cd}$ is more deleterious than $\mathrm{Pb}$ on the kidney function. Staessen et al. (1992) found significant inverse associations between $\mathrm{Pb}$ and creatinine clearance. In addition, Järup, et al. (2000) and Järup (2002) showed that cadmium exposure is related to early renal effects. Also, Alfvén, et al. $(2000,2002)$ found a relationship between cadmium concentrations in the body and tubular proteinuria (as indication of kidney damage) and not found such associations for blood lead. On the other hand, chronic exposure to high levels of heavy metals results in irreversible changes in the kidney in experimental animals (WHO, 2005). These functional changes are thought to be related to an effect of these heavy metals on mitochondrial respiration and phosphorylation (Nolan and Shaikh, 1992). Weaver et al. (2005) suggested that uric acid may be one of the mechanisms for heavy metals-related nephrotoxicity.

In conclusion, animals reared on sewage-polluted pasture accumulate higher $\mathrm{Pb}$ and $\mathrm{Cd}$ in the kidney and liver than the recommended levels for health of these animals and for human consumption. These metals cause degenerative changes in the kidney and liver tissues. The kidney and liver function tests are strongly correlated with $\mathrm{Cd}$ and to less extent with $\mathrm{Pb}$ residues in these tissues.

\section{REFERENCES}

Abou-Arab, A.A. (2001): Heavy metal contents in Egyptian meat and the role of detergent washing on their levels. Food Chem Toxicol. 39: 593-599. 
Alfvén, T.; Elinder, C.G.; Carlsson, M.D.; Grubb, A.; Hellström, L.; Persson, B.; Pettersson, C.; Spång, G.; Schütz, A. and Järup, L. (2000): Low level cadmium exposure and osteoporosis. J Bone Miner Res 15:1579-1586.

Alfvén, T.; Järup, L. and Elinder, C. (2002): Cadmium and lead in blood in relation to low bone mineral density and tubular proteinuria. Environ Health Perspect 110: 699-702

AOAC (1995): Official Methods of Analysis of Association of Official Analytical Chemists, Vol. 1, $16^{\text {th }}$ ed. AOAC International, Arlington, VA, pp. 4/1-4/30.

ATSDR (2005): Toxicological profile for lead (update). (Agency for Toxic Substances and Disease Registry.) U.S. Department of Health and Human Services, Atlanta, GA.

Babu, K.R.; Rajmohan, H.R.; Rajan, B.K. and Kumar, K.M. (2006): Plasma lipid peroxidation and erythrocyte antioxidant enzymes status in workers exposed to cadmium. Toxicol Ind Health. 22: 329-335.

Blasco, J. and Puppo, J. (1999): Effect of heavy metals (Cu, Cd and $\mathrm{Pb}$ ) on aspartate and alanine aminotransferase in Ruditapes philippinarum (Mollusca: Bivalvia). Comp Biochem Physiol: Pharmacol Toxicol Endocrinol.; 122: 253-63.

Borenstein, M; Rothstein, H. and Cohen, J. (1997): Sample Power Statistics. 1.0. SPSS Inc., Chicago.

Burtis, C.A. and Ashwood, E.R. Eds. Tietz Textbook of Clinical Chemistry. $2^{\text {nd }}$ ed. Philadelphia. W.B. Saunders. pp 1974-2043.

CEC (2001): Setting Maximum Levels for Certain Contaminants in Foodstuffs. Commission Regulation EC No. 466/2001. Official Journal of the European Communities Brussels. Commission of the European Communities. 77/1-77/12.

Coles, E.H. (1980): Veterinary Clinical Pathology, 3rd ed. W.B. Saunders Co., Philadelphia, pp. 48-49.

Damek-Poprawa, M. and Sawicka-Kapusta, K. (2004): Histopathological changes in the liver, kidneys, and testes of bank voles environmentally exposed to heavy metal emissions from the steelworks and zinc smelter in Poland. Environm Res. 96: 7278.

El-Sharkawy, E. Eman; El-Kattan, Y.A; Senousi, S.A. and Saleh, M.A. (2008): The relation between heavy metals and trace elements levels in blood of sheep reared on sewage-polluted plants. Assiut Vet. Med. J. 54: 156-168. 
Fick, K.R.; Ammerman, C.B.; Miller, S.M.; Simpson, C.F. and Loggins, P.E. (1976): Effect of dietary lead on performance, tissue mineral composition, and lead absorption in sheep. J. Anim. Sci. 42: 515-520.

Gomah, H.H. (2001): Assesment and evaluation of certain heavy metals in soil and plants in Assiut governorate. Ph. D. Thesis, Fac. Agric. Assiut Univ.

Henry, R.J.; Cannon, D.C. and Winkelman, J.W. (1974): Clinical Chemistery, Priciples and Techniques. $4^{\text {th }}$ Ed., Harper and Row; Hagerstown M D.

Hsu, P. and Guo, Y. (2002): Antioxidant nutrients and lead toxicity. Toxicology 180: 33-44

Järup, L. (2002): Cadmium overload and toxicity. Nephrol Dial Transplant.; 17 (Suppl 2): 35-9.

Järup, L.; Hellstrom, L.; Alfven, T.; Carlsson, M.D.; Grubb, A.; Persson, B.; Pettersson, C.; Spang, G.; Schutz, A. and Elinder C.G. (2000): Low level exposure to cadmium and early kidney damage: the OSCAR study. Occup Environ Med 57: 668-672

Kowalczyk, E; Kopff, A.; Fijalkowski, P.; Kopff, M.; Niedworok, J.; Blaszczyk, J.; Kędziora, J. and Tyoelerowicz, P. (2003): Effect of anthocyanins on selected biochemical parameters in rats exposed to cadmium. Acta Biochim Pol. 50: 543-548

McDowell, L.R. (2003): Minerals in Animal and Human Nutrition, $2^{\text {nd }}$ ed. Elsevier Science, Amsterdam.

Neathery, M.W; Varnadoe, J.L.; Miller, W.J.; Crowe, C.T.; Fielding, A.S. and Blackmon, D.M. (1990): Effects of High Dietary Lead on the Metabolism of Intravenously Dosed Selenium-75 in Dairy Calves. J. Dairy Sci. 73: 1107-1112

Nolan, C.V. and Shaikh, Z.A. (1992): Lead nephrotoxicity and associated disorders: biochemical mechanisms. Toxicol 73:127-146.

Phillips, C.J.; Chiy, P.C. and Omed, H.M. (2004): The effects of cadmium in feed, and its amelioration with zinc, on element balances in sheep. J. Anim. Sci. 82: 2489-2502.

Prankel, S.H.; Nixon, R.M. and Phillips, C.J.C. (2004): Meta-analysis of feeding trials investigating cadmium accumulation in the livers and kidneys of sheep. Environm Res 94: 171-183.

Shaikh, Z.A.; $V u$, T.T. and Zaman, K. (1999): Oxidative stress as a mechanism of chronic cadmium-induced hepatotoxicity and renal toxicity and protection by antioxidants. Toxicol Appl Pharmacol. 154: 256-263. 
Smith, S.R. (1995): Organic pollutants. In: Agricultural Recycling of Sewage Sludge and the Environment. Wallingford, UK:CAB International pp. 207-236.

Staessen, J.A.; Lauwerys, R.R.; Buchet, J.P.; Bulpitt, C.J.; Rondia, D.; Vanrenterghem, $Y$. and Amery, A. (1992): Impairment of renal function with increasing blood lead concentrations in the general population. The Cadmibel Study Group. N Engl. J. Med. 327: $151-156$.

Stoev, S.D.; Grozeva, N.; Simeonov, R.; Borisov, I.; Hubenov, H.; Nikolov, Y.; Tsaneva, M. and Lazarova, S. (2003): Experimental cadmium poisoning in sheep. Exp Toxicol Pathol. 55: 309-314.

Tenant, B.C. (1997): Hepatic function. In Clinical Biochemistry of Domestic Animals. 5th ed. Kaneko, J. J., Harvey, J. W. and Bruss, M. L., Academic press, London. pp327-352

Thornton, I. (2002): Geochemistry and the mineral nutrition of agricultural livestock and wildlife. Appl Geochem. 17: 10171028.

Underwood, E.J. and Suttle, N.F. (1999): The Mineral Nutrition of Livestock. $1^{\text {st }}$ ed. CABI Publishing, Wallingford.. pp 543-586.

Weaver, V.M.; Jaar, B.G.; Schwartz, B.S.; Todd, A.C.; Ahn, K; Lee, S.; Wen, J.; Parsons, P.J. and Lee, B. (2005): Associations among lead dose biomarkers, uric acid, and renal function in Korean lead workers. Environ Health Perspect 113: 36-42.

WHO (2005): Environmental Health Impacts from Exposure to Metals. Report of a Joint Interregional Workshop 1-3 June 2005, Simla, India. pp 3-5.

Wilkinson, J.M.; Hill, J. and Livesey, C.T. (2001): Accumulation of potentially toxic elements in the body tissues of sheep grazed on grassland given repeated applications of sewage sludge. Anim Sci. 72:179-190. 